\title{
伸筋腱が整復障害因子となった橈骨遠位骨端離開の一例
}

\author{
大分県済生会日田病院整形外科 \\ 石 田 漂 太・安 藤 則 行 \\ 聖マリア病院整形外科 \\ 吉田 健 治
}

久留米大学医学部整形外科学教室

山田康人·副島崇
井上 明生

\section{A Case of Epiphyseal Separation of Distal Radius Due to Interposition of Extensor Digitorum Communis}

\author{
Hyota Ishida, and Noriyuki Andoh \\ Orthopaedic Surgery, Saiseikai Hita Hospital \\ Kenji Yoshida \\ Department of Orthopaedic Surgery, \\ St. Mary's Hospital, Kurume, Japan \\ Yasuto Yamada, Takashi Soejima, and Akio Inoue \\ Department of Orthopaedic Surgery, \\ Kurume University School of Medicine
}

\begin{abstract}
We reported a case with epiphyseal separation of the distal radius which could not be reduced by nonsurgical manipulation due to interposition of the extensor digitorum communis tendon. The case was a 12 -year-old boy who was injured by falling down from a running bicycle. X-ray findings showed markedly separated distal epiphysis of the right radius with fracture of the distal ulna. In spite of manipulation under anesthesia, the epiphyseal separation was irreducible. Operative findings showed that the extensor digitorum communis tendon was interposed between the separated radial fragments. Radius was fixed by Kirschner wires following surgical reduction.
\end{abstract}

Key words : extensor tendon (伸筋腱), irreducible (整復障害), epiphyseal separation（骨 端離開）

はじめに

軟部組織が整復障害因子となった前腕端部の骨折, 骨端離開は, 数例の報告がみられるのみである.今回 我々は, 総指伸筋腱が整復障害因子となった橈骨遠位 骨端離開の症例を経験したので報告する。
症

例

症例 : 12歳 男性

主訴: 両手関節痛および変形

現病歴 : 自転車走行中に転倒し受傷した。詳細な受傷 肢位は不明であった。直後に近医受診し徒手整復施行 され，左側は整復可能であったが整復位保持困難であ

り，右側は徒手整復困難なため同日当院を紹介された. 


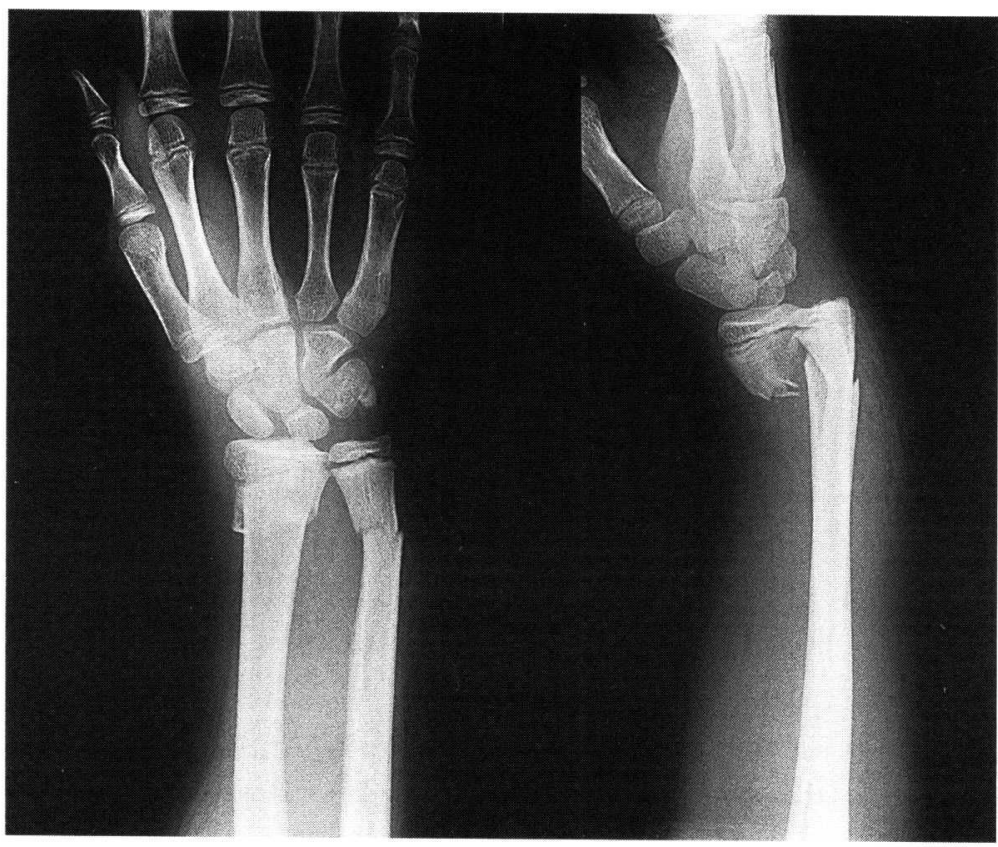

図 1 受傷時レントゲン 掌側に転位したSalter-Harris II 型の橈骨遠位骨端離開と尺骨遠位端骨折を認 めた。

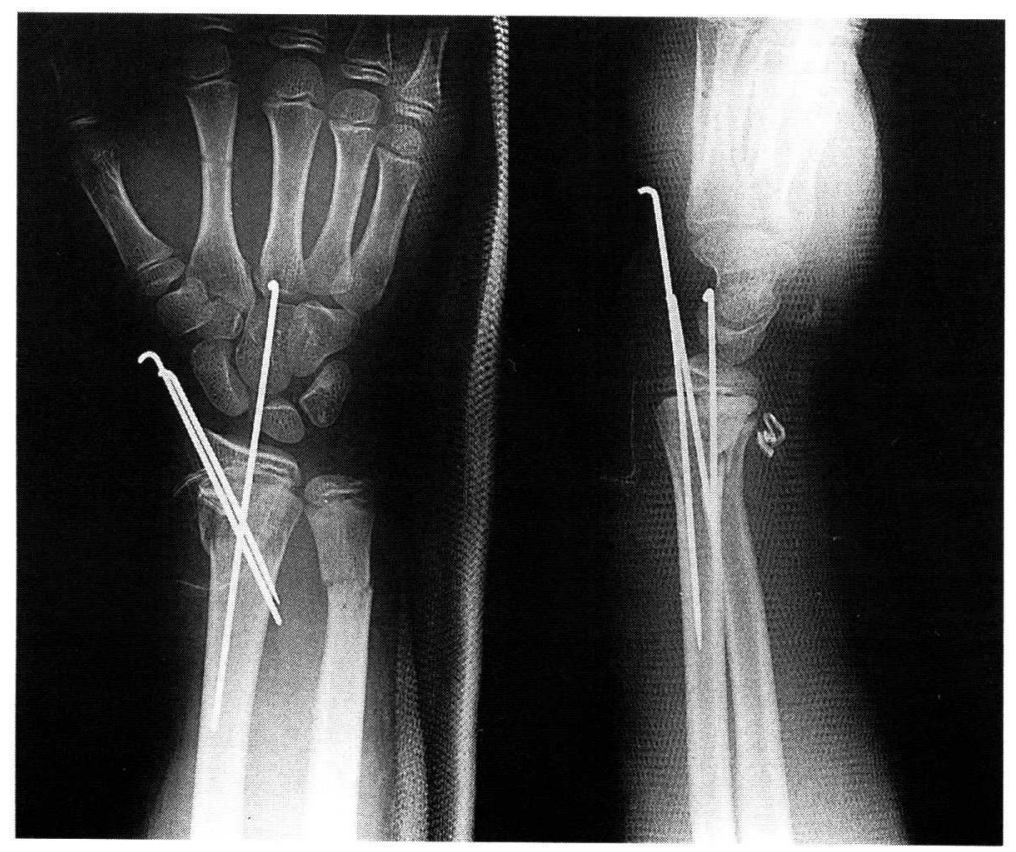

図 2 術後レントゲン

観血的に整復しキルシュナー鋼線にて骨折部を固定した. 
初診時現症 : 右手関節周辺は著明に腫脹し，背側凸の 変形を認めた. 手指の運動に伴う手関節周辺の疼痛を 認めた. 神経症状は認めなかった。

初診時 X 線所見 : 掌側に転位した Salter-Harris II 型 の橈骨遠位骨端離開と尺骨遠位端骨折を認めた（図 1).

直ちに徒手整復を試みたが，整復不能であったため 中手骨より鋼線牽引を施行した，整復位が得られなかっ たため、受傷 2 日後に観血的整復術を施行した。右手 関節橈背側に皮切を加えると, 皮下組織の直下に骨折 部が展開され, 本来, 皮切部直下に存在するべき総指 伸筋腱が認められず, 骨折部の近位で橈掌側に転位し た同筋腱を確認した. エレバトリウムを橈骨の橈側に 挿入し同筋腱を挙上するようにして整復を行なった。 骨折部はキルシュナー鋼線を用いて固定した（図2）.

\section{考察}

軟部組織の介在により徒手整復不能となった前腕末 端部の骨端離開, 骨折の報告は数件が散見されるのみ である ${ }^{1-6)}$. 手指伸筋群は, 橈骨遠位端では伸筋支帯 により骨と強固に連絡されているのに対し，骨幹端部 では連絡性にそしい．このため受傷時の外力の加わっ た方向によっては骨片間への筋腱の介在がおこりえる と考えられる. 本症例では, 総指伸筋腱は末梢骨片と ともに中枢骨片の橈側を掌側に向い両骨片間に介在し たと考える. 本症例のごとく保存的に整復不能な前腕 末端部の骨折では, 軟部組織が介在し整復障害因子と
なりうる事を認識し治療をすすめる必要がある.

$$
\text { ま と め }
$$

(1)総指伸筋腱が整復傷害因子となった橈骨遠位骨端 離開の 1 例を報告した。

(2)保存的に整復困難な前腕末端部の骨折の治療に際 しては，軟部組織の介在の可能性を認識し治療をすす めるべきである.

\section{参 考 文 献}

1) Holmes, J.R., Louis, D.S.: Entrapment of pronator quadratus in pediatric distal-radius fractures: Reconstruction and treatment. J. Pediatr Orthop., $14:$ :98-500, 1994.

2) Hunt, D.: Dislocation of the extensor pollicis longus tendon in Smith's fracture of the radius. J. Bone Joint Surg., 51-A : 991-994, 1969.

3) Itoh, Y. et al.: Extensor tendon involvement in Smith's and Galeazzi's fractures. J Hand Surg., 12A : 535-540, 1987.

4）二田水節, 秋吉一明：尺側手根伸筋（ECU）が整復障 害となった両側尺骨遠位骨端線離開の 1 例. 整外と災外, 32 : 705-706, 1984.

5) McDaniel, W.J. et al.: Irreducible fracture of the distal end of the ulna. J. Bone Joint Surg., 55-A : 1297-1298, 1973.

6）若狭雅彦ら：尺側手根伸筋が整復障害因子となった尺 骨遠位骨端線離開の1例．整外と災外，35：188-190， 1986. 